\title{
The Principal-Agent Approach to Politics: Policy Implementation and Public Policy-Making
}

\author{
Jan-Erik Lane \\ University of Freiburg, Freiburg im Breisgau, Germany \\ Email: janeriklane34@googlemail.com
}

Received December 29 $9^{\text {th }}, 2012$; revised February $12^{\text {th }}$, 2013; accepted March $7^{\text {th }}, 2013$

\begin{abstract}
Copyright (c) 2013 Jan-Erik Lane. This is an open access article distributed under the Creative Commons Attribution License, which permits unrestricted use, distribution, and reproduction in any medium, provided the original work is properly cited.
\end{abstract}

\begin{abstract}
The principal-agent models may be employed to elucidate central problems in interaction between principals and agents in both policy implementation and public policy-making concerning performance and remuneration. One then hits upon the double principal-agent relationships that are typical of the policy cycle, from policy-making to policy implementation and back: 1) government as principal for agents in public service delivery; 2) the population as principal for political agents under various forms of rulership.
\end{abstract}

Keywords: Principal-Agent Interaction; Asymmetric Information; Moral Hazard; Adverse Selection; Bureaucracy; New Public Management; Rule of Law; Long-Term Contracting; Short-Term Contracting; Looting

\section{Introduction}

In a world of politics based upon perfect and symmetric information, an imaginary world of politics along Downs' 1957 well-known model of two-party system competition in a presidential type regime, the demos as principal would contract with the correct politicians as agents, promising the making of the policies that majority group in the principal favours. Politicians would be paid a decent salary, somehow above their fixed reservation price. But there would be no need for rents or quasi-rents. Politicians who performed better in terms of a goal like for instance affluence or GDP growth would be favoured ahead of politicians who performed badly, the re-election mechanism doing the selection of agents for the demos.

Given perfect knowledge, voters would pick political agents on the basis of the proximity rule, minimising the policy distance between their own political preferences and those of the politicians in government and the legislature. Thus, radical left-wing leaders like Lenin, Stalin or Mao would not be chosen in free and fair elections, when the electore would know about their hidden agenda. Ringht-wing leaders like Hitler, Mussolini and France could only for chosen in the first election before their hidden agenda had been revealed to the population, having then experience the empthiness of national chauvinism.

Principal-agent games under perfect information would resemble the referendum democracy or a representative regime with imperial mandates. In a two-party system in Downs' model, the principal would elect the agents they want, pay them in a straightforward manner as well as receive the policies they prefer. With no rents, opportunism would not work. Besides, one may assume that politicians in these games are driven by vocation, as with Max Weber's model of the ideal agent politi-

* This article is based upon a talk at the University of Haifa with the School of Political Sciences, November 2012. cian.

The same-first best solution or perfect equilibria—would be found in the implementation of policies under perfect and symmetric information. The government as principal would hire a set of bureaux to do the job, i.e. provide a set of public services. These bureaux would be paid a decent remuneration, hired on long-term contracts with promise of predicatble pension in order to make sute they develop expertise on policy matters. Given a sharp distinction between policy-making and policy implementation, the bureaux would focus their attention upon the means to achieve goals, maximising efficiency and effectiveness in policy technology as well as neutrality in politics, along lines suggested by Weber's ideal-type model of the bureaucracy.

The introduction of asymmetric information changes all of this, allowing for the search for rents or quasi rents by agents engaging in opportunism.

\section{The Principal-Agent Model}

Two conspicuous features in the politics and policy-making in the early 21st century include:

1) Policy implementation: The increased externalisation of public services provision;

2) Policy-making: The increasing call for clean politics and restraints upon politicians.

The first is linked with the success of the NPM reform movement, which was based upon a critique of the classical model of bureaucracy of Weber (Weber, 1978: pp. 956-1002), whereas the second involves a rejection to the ideal model of the politician, also launched by Max Weber in "Politics as a vocation" (Weber, 1991: pp. 77-129). Both of these major events in politics today may be analysed in terms of the perspective upon politics and policies launched by the princi- 
pal-agent model. It asks pertinently:

1) Which agents are to be employed in policy implementation?

2) Can politicians as agents of demos be trusted, under what rules of the game?

The principal-agent model identifies two major difficulties when a principal contracts with a set of agents under asymmetric information, namely moral hazard (hidden action) and adverse selection (hidden knowledge). These two difficulties surface whether the contract is explicit and enforceable in court, as with policy implementation, or the contract is opaque and only enforceable to a limited extent, as with politics.

The principal-agent model has been applied in various private sector settings, such as the remuneration of CEOs, the choice of contracts in agriculture and the client-lawyer interaction (Rasmusen, 2006). When it is applied to politics, then one must model a double principal-agent interaction, starting backwards with first the government choice of agents who will handle the provision of services and moving then to the choice of the electorate of political agents with different policy preferences.

The most simple principal-agent model analyses the interaction between a risk prone principal and a set of risk avert agents, where the former hires the latter on the basis of a contract involving work effort, salary plus perks involving a basic quid pro quo, whereby the agents are paid from the value of the output they deliver. The agents may deliver low or high effort, which has implications for the probabilities of low or high output. As the principal aims for high output, he/she wants to write a contract that elicits high effort. But all contracts are subject to two basic principles that must be satisfied: the reservation price of the agents on the one hand and incentive compatibility on the other hand. With perfect information one may calculate first best solutions that satisfy these requirements. However, given asymmetric information-hidden actions and hidden knowledge, one has to face suboptimal solutions. They are actually well-known in the literature on bureaucracy and comparative politics, although the language of the principal-agent model has not been used.

The Niskanen model of bureaucracy with the public choice school is a principal-agent model where the agents employ their information advantage to supply a non-optimal level of public services. In non-democratic politics, the rulers monopolize the benefits in politics, sometimes reducing the population to a form of political slavery (Burma), but always restrict the choice of the electorate, in order to make looting easier. The opposite solution, exploitation, is also feasible, for instance in agriculture with powerful landlords (zamindars) employing indentured labour or controlling sharecropping contracting (McLane, 1993).

Between these two extreme solutions, exploitation by the principal versus looting by the agents, one finds all kinds of varying solutions concerning both the value produced and the division of the mutual gains from interaction. The output can be either private or public services and the value of the output may be calculated with market prices or the willingness of tax payers to pay. One application of the principal-agent model was less focussed upon rent seeking and targeted more prestige. The public choice model of public regulation claimed that it had a fundamental credibility problem, as regulators would like to deviate from the original policy intentions behind regulatory schemes.
Below, we focus upon the struggle between the principal and the agents about the division of the monetary gains from cooperation. When agents are self-centred and do not refrain from opportunism with guile, then what strategies can they employ in order to get an extra payment using asymmetric information?

\section{Agency Costs}

The population as principal has to carry two kinds of agency costs. First, there is the remuneration of political elites, both pecuniaty and non-pecuniary. The direct costs may go very high in non-competitive regimes, as looting is much more probable in them. Second, there are the indirect costs from dire agent performance or mistakes, which could go as high as the complete loss of huge national assets or political territory. Political leaders may promise paradise on Earth, but accomplish only destruction. "Mission accomplished", declared President Bush, only to have to face the strong insurrection in Iraq that costs so much in terms of peoples' life, American causalties and misspent trillions.

First, politicians wish to have discretion on policies in telation to their voters, which is what asymmetric information provides. Thus, they claim that they have a general mandate from the population to search for the policies that are in the national interest. Politicians have their own agenda, open or hidden. The election contract tends to be little specific, often general or ambiguous. It is a fundamentally incomplete agreement, allowing the politicians as agents much space to maneouvre in relation to unforseen circumstances, or the contingencies. The politicians may set up a multi-party system, which would make coalitions possible beyond the horizon of their voters.

Given such opaque election contracts, the politicians would wish to amass consierable amounts of resources to allow them to operate freely, either as parties (partitocrazia) or as indepenents (political entrepreneurs). And they would wish to maximise the resources for the conduct of their business, either by state contributions to parties (Europe) or by means of society contributions through e.g. the PAC system in the US. These resources-spolia - will be used to remunerate or give favours to the people who helped them win elections, using massive propagande to convince the principal about their suitability as political agents. Thus, party government emerges with massive rent seeking where the political elite has a formidable knowledge advantage over the population.

Second, under asymmetric information the implementation agents will embark upon various opportunistic startegies that increase their remuneration, pecuniary or non-cuniary ones. Thus, bureaucracies and public enterprices exploit the budget maximising strategy-shirking. The move of government to New Public Management, i.e. tendering/bidding under a regime of short-term contracts, will stop moral hazard in the public sector, but it invites adverse selection as agents bid who are not trustworthy or reliable. Managing tournaments and auctions will be as difficult as to monitor huge bureaux for government as the principal of the public sector.

Agency costs, like e.g. the spoils of competitive politics are motivated by the classical Burke theory of politicians as the guardians of the general interests of the principal. But who knows the true interest of the population-asymmetric information?!

Sometimes the rent-seeking ambitions of political agents lead them to engage in illegal activities: 
- Patronage,

- Embezzlement,

- Corruption;

- Tax evasion;

- Kick backs and commissions on public contracts.

An economic rent is an unearned income, meaning an excessive remuneration compared with what had to be paid, or it is a payment in excess of the opportunity cost. The theory of economic rents has concentrated upon monopoly profits, collusion gains from oligopolistic competition, as well as rents for lobbying government to secure lucrative contracts or favourable regulation (Tullock, 2005). Rents figure prominently in princi-pal-agent interactions, whether as pecuniary or non-pecuniary advantages. The nature of the political regime-its basic structure of public law-affects how political agents maximise the rents.

Non-Competitive Regimes: In a traditional or authoritarian regime, like Saidi Arabia or North Korea, political agents tend to take such a huge part of total output (GDP) that one is allowed to speak of looting. Thus, the remuneration of the large Saidi family is immense, comprising all kinds of income, perks and capital assets, home or abroad. In North Korea, the entire country has been mobilised to provide favours and advantages to the clan of the ruling family. Charismatic regimes like the Maoist rulership in China involve enormous agency costs, both direct in supporting Mao and his entourage, as well as indirect ones, resulting from mistaken policies.

Competitive Regimes: The agency costs for political regimes that have open access tend to be much lower than those of closed regimes. Thus, when political agents cause costly mistakes to the population, they will probably be voted out of office. However, also competitive regimes run with economic rents for the politicians.

Politicians or political parties have an unsatiable need for resources in order to maintain themselves and their advantageous positions in society, as there are considerable costs of competition. Thus, they employ all kinds of ways to bolster their coffers: high salarier for representative positions, political appointments in the bureaucracy, campaign contributions, "cumul des mandates", close connections with support groups (industry, labour, and agriculture), public contributions to newspapers affiliated with parties, subsidised educations courses by affiliated orginisations, tax reductions for trade union fees and payments to think tanks, etc.

\section{Value of Output, Remuneration and Rent}

The agents hired by the principal to deliver a valuable output must of course be paid somehow for their work and effort. The payment of the agents comes out of the value of the output, either directly through market prices or indirectly through taxation and public fees. All other things equal, the agent wants as large remuneration whatever its forms as possible whereas the principal remains the residual claimer, thus being interested in maximising the difference between the value of output-agent remuneration.

What the agent is paid in pecuniary and non-pecuniary forms of remuneration depends upon their effort, the reservation price and incentive compatibility, given asymmetric information. The occurrence of conditions for moral hazard or adverse selection opens up for strategies of opportunism on the part of the agents, attempting to get hold of an extra remuneration, a so-called rent in economic theory. Long-term contracting invites the option of shirking, whereas adverse selection provides for opportunities of pretending.

\section{Policy Implementation: From Moral Hazard to Adverse Selection}

The NPM (New Public Management) revolution in public administration emerged from a background of weariness with big government, public deficits and government overload in the mature welfare state. Intellectually, it was much inspired by public choice theories, especially their criticism of long-term contracting, as with bureaucracy and the public enterprises. Both bureaucracy and the public enterprise were institutional mechanisms that invited one key strategy from the agents, namely shirking. Given asymmetric information, government would be in a weaker position, having to take whatever cost increases the bureau or public enterprise came up with. Both the bureau and the traditional trading department captured an excessive remuneration by expanding activities beyond what was optimal, resulting in excessive number of employees and costs. In reality, there was here a form of moral hazard, as the risk ended up one-sidedly with government whereas the benefits would be mostly with the bureau or public enterprise. In long-term contracting, promises are cheap, and memory is short concerning what was promised when outcomes turn up that are undesirable.

NPM recommended short-term contracting as a strategy to strengthen the position of the principal in relation to the providers of public services. Instead of bureaucracy and the traditional public enterprise, the principal would apply the following mechanisms suitable for short-term contracting:

1) Outsourcing;

2) Tournaments;

3) Auctions;

4) Incorporation.

All these mechanisms involve the employment of tendering-bidding that replaces the authority structure with the capacity of government to exercise authority over its bureaux and employees. Government gives up its power to plan and direct the agents responsible for policy implementation in order to buy specific services in accordance with a private law contract, specifying performance as well as quantities and quality. The public law governed budgetary process is undone, as the private law contract is supposed to cover the most relevant contingencies, including costs and service quantity and quality. Government becomes a contractor, employing private law to arrange for the provision of services. Public ownership is transformed through incorporation into the holding of assets through aktien, i.e. a private law institution. Government hires agents to manage its capital assets in accordance with private management principles, focussing upon rentability in the first place.

The move from long-term contracting to short-term contracting entails that government has to struggle with the problem of adverse selection, i.e. how to figure out which agents who are forthcoming to bid for all the government contracts can be trusted. Government is bound to run into massive transaction costs when it moves from bureaucracy to tendering-bidding, as conflicts arise about what has been agreed upon. Contracting presupposes considerable time and effort for negotiation and may involve substantial costs for enforcement as 
well as dispute settlement in courts or outside.

Nothing guarantees that government will be able to reduce its overall costs or increase performance in service delivery, when moving from long-term contracting to short-term contracting. Just as a number of strategies can be used by agents to shirk under long-term contracting arrangements, so alternatives ways for agents to engage in opportunism exist under shortterm contracting, all allowing for agents to pretend they are better than they really are. It may indeed be costly for government to correct these pretending strategies, incurring switching costs when turning to another set of agents or being forced to pay more for unforeseen costs besides loosing court cases where agents exploit badly written contracts.

The principal and the agents have common interests in the agents delivering a big output of value, but agents will only try hard when incentive compatibility is met by the principle. Nothing prevents the agent from demanding a huge remuneration for pretending high effort, i.e. to engage in the opportunism of looting. When the traditional public enterprise is incorporated and deregulated, then the temptation of the looting strategy may be irresistible. Thus, with incorporation the number of employees goes down and profits go up, but the salaries of the key CEO:s tend to skyrocket, especially when large public corporations turn to regional or global strategies outside of the home country.

\section{Policy Implementation: Hidden Actions and Adverse Selection}

When governments set out to deliver a set of public services, they have to rely upon sets of agents. The classic model of public administration outlined a set of bureaux with specialised functions, accumulating expertise over time. However, under long-term contracting agents have incentives to capture a rent due to asymmetric information. This rent from shirking may consist of X-inefficiencies or merely too much employment. The controller of the bureau-the Ombudsman-would investigate the occurrence of hidden actions among the agents, i.e. violations of the public law framework of bureaucracy.

Public sector reform during the last twenty years has turned to short-term contracting to remove this rent, favouring externalisation of the delivery of public services, including the incorporation of the big public enterprises. However, with tendering-bidding and short-term performance contracting come adverse selection, which provides the agents with another type of opportunistic strategies in order to capture a rent from pretending. The principal has to assume considerable transaction costs in order to handle the implications of adverse selection

\section{Policy-Making and Asymmetric Information}

The agency problems involved in hidden action and hidden knowledge characterize not only the implementation of policy, but they figure prominently also in politics as policy-making: Can the demos as principal trust its politicians as their agents for the making of public policies?

The distrust in political elites was theorized in the so-called elite theory with the three Machiavellians: Pareto, Mosca and Michels. They argued that politicians develop their own agendas in order to promote their special elite interests, capturing a rent by means of opportunistic strategies.
Elite theory was much criticised by pluralist theory, mainly by means of the argument that political elites tend to be pluralistic in terms of both origins and composition. However, this counter-argument does not take into consideration that political elites from various backgrounds-social and ideological, engage in hidden actions and employ hidden knowledge to increase their remuneration in a broad sense of the term, covering both pecuniary and non-pecuniary rewards.

Moral hazard pocketing any favourable outcomes-merely luck, while placing the risk with the country or blaming - unforeseeable negative results-occurs often in politics. Similarly adverse selection is omnipresent, especially in elections where the demos has difficulties in evaluating electoral promises as realistic or unrealistic ones. The rationale of constitutionalism in politics derives from its contribution to undo asymmetric information, revealing hidden actions and hidden knowledge among the political elite.

Thus, the mechanisms against political opportunism are handed down in the theory of rule of law, including:

1) Judicialisation of politics;

2) Referendum and recall;

3) Parliamentary opposition;

4) Federalism or political decentralization;

5) Civil society involvement;

6) Re-election of politicians: limits on tenure, primaries, etc.

Constitutional democracy consists of a number of institutions that counteract the implications of political elitism. These institutions divide up the set of political agents into competing sets with the consequences that asymmetric information is reduced considerably for the demos. Opportunistic strategies based upon hidden knowledge-bad politicians-or hidden actions-illegal manoeuvres-trigger responses or counter strategies. In a rule of law regime, bad politicians are-sometimes at least-eliminated and illegal practices punished. More specifically, public law restrains the solutions to the principal-agent problematic through the following: Predictability: Public law when properly implemented makes it possible for people to increase the rationality of behaviour. They know what rules apply, how they read as well as how they are applied consistently. This is very important for the making of strategies over a set of alternatives of action.

Transparency: Societies operate on the basis of norms prohibiting, obligating or permitting certain actions in specific situations. Rule of law entails that these norms are common knowledge as well as that they are not sidestepped by other implicit or tacit norms, known only to certain actors.

Due Process of Law: When conflicts occur either between individuals or between persons and the state, then certain procedures are to be followed concerning the prosecution, litigation and sentencing/incarceration. Thus, the police forces and the army are strictly regulated under the supervision of courts with rules about investigations, seizure, detainment and prison sentencing. No one can take the law into their own hands.

Immunities: People have certain rights against the state, meaning that government faces definitive duties concerning the protection of life, personal integrity and property. One may call them the habeas corpus rights.

Counter-weighling Powers: Under the rule of law regime there could be no single source of political power, or a hierarchical order of command. Instead, it favours multiple centres of power, or pluralism. In terms of religion, it adheres to a secular state based upon religious tolerance. 
Separation of Powers: In order to have respect for the law as the key instrument for governing society and regulating the state, legislation, policy-making and implementation as well as law adjudication must somehow be separated. Under rule of law this separation of powers targets the political elite active in the state, with the claim that it has to be divided into three different elites: legislators, governors or governments and courts. These classic functions in the state cannot be exercised by one and the same set of political elites. Separation of powers enhances checks and balances ingovernment as well as counterweighing powers.

Fairness: Public law comprises a number of mechanisms that promote not only the legal order, or the law, but also justice, or the right. For ordinary citizens, the principle of complaint and redress is vital, providing them with an avenue to test each and every decision by government, in both high and low politics. Here one may emphasize the existence of the Ombudsman, as the access to fairness for simple people.

\section{Conclusion}

Politics is both policy-making and policy implementation. The demos selects and instructs a set of agents-the politicians - to come up with a list of policies that the demos prefer. Yet, the politicians do not have time or expertise to put these policies into practice, which is why they-as principals - rely upon a set of agents to deliver public services. Thus, one arrives at the double nature of principal-agent interactions in politics.

One may interpret the move from bureaucracy to New Public
Management as the search for strategies that reduce the asymmetric information advantage of bureaux. NPM helps against shirking but invites another form of opportunism, namely pretending. Adverse selection is not a major problem in long-term contracting, as the principal has a general authority to direct the work of the agents. But in short-term contracting, the selection of bad agents can only be corrected by high transaction costs, as failure to fulfil a contract will often be contested in court. Shirking may of course also occur in short-term contracting.

The huge attention given to political scandals in present day politics fits well into a principal-agent approach to elections and policy-making. Politicians as elite have incentives to capture a rent by means of all kinds of opportunism. Only the rule of law regime can counteract the consequences of hidden actions and hidden knowledge.

\section{REFERENCES}

Burke, E. (1999). The portable edmund burke. London: Penguin. McLane, J. R. (1993). Land and local kingship in eighteen century Bengal. Cambridge: Cambridge University Press. doi:10.1017/CBO9780511563348

Rasmusen, E. (2006). Games and information. Oxford: Blackwell. Tullock, G. (2005). The rent seekig society. Washington, DC: Liberty Fund.

Weber, M. (1978). Economy and society I-II. Berkeley: University of California Press.

Weber, M. (1991). From max weber: Essays in sociology. B. S. Turner, H. H. Gerth, \& C. W. Mills, Edited. London: Routledge. 